Covered in: ERIH PLUS, CEEOL, Index Copernicus, CrossRef, CrossCheck, J-Gate, Google Scholar, Ideas RePeC, Econpapers, Socionet, KVK, WorldCat.

\section{A Reading of Sandu Frunză's Readings: Filosofie și comunicare cotidiană. Cărțile ar putea să-ți schimbe viața [Philosophy and Daily}

Communication. Books Could Change Your Life], Lumen Publishing House, 2020

\section{Florin CHERMAN1}

${ }^{1}$ Master's student, Faculty of History and Philosophy of Babeș-Bolyai University of Cluj-Napoca, Romania, florincherman66@gmail.com
Abstract: Is it still necessary to read books? Why should we, if we generally should, read more books? Why should we tire ourselves by doing this activity, when technology gives us so many other ways to consume the information we need or don't need? Why get bored with long, still texts, without images, trying to penetrate the meaning of their words, often distributed among the beautiful but difficult to probe formulations, when we have the alternative of receiving information through other sources, much more user-friendly? This paper is a review of the volume "Filosofie și comunicare cotidiană. Cărțile ar putea să-ți schimbe viața" [Philosophy and everyday communication. Books could change your life], written by Sandu Frunză and published at Lumen Publishing House from Iași in 2020.

Keywords: Philosophy; communication; reading; Sandu Frunză.

How to cite: Cherman, F. (2020). A Reading of Sandu Frunză's Readings: Filosofie și comunicare cotidiană. Cărțile ar putea să-ți schimbe viața [Philosophy and Daily Communication. Books Could Change Your Life], Lumen Publishing House, 2020. Logos Universality Mentality Education Novelty: Philosophy \& Humanistic Sciences, 8(2), 125-129. https://doi.org/10.18662/lumenphs/8.2/52 
What do we do, after all, when we read a book? I have always liked to see reading as a dialogue between me, as a reader, and the author, as the one who shares with me his experience, emotion and involvement. An indirect dialogue, mediated through the pages of the book in such a way that I can have this dialogue despite the hundreds of years or kilometers that separate me from the author: him, the author, left to me, ans particularly to me, a message on paper, for me to receive. While experiencing a somewhat strange sense of contemporaneity with each of these authors, I can know the faculties of the soul from Aristotle, wake up from the dogmatic sleep with Kant, and then relive, with tears in my eyes, what happened to Jean -Baptiste Clemence one evening on the quay of the Seine, and how that sound of falling into the water followed him until it completely transformed his existence.

These similar questions and thoughts aroused my reading of the book Filosofie și comunicare cotidiană: Cărțile ar putea să-ți schimbe viața [Philosophy and Everyday Communication: Books Could Change Your Life], written by Sandu Frunză (2020). Regarding the above questions, the title of the book already contains the author's answer: yes, reading books is still necessary and we have to do it because them, the books, could change our lives.

Before opening the book and entering into the indirect and mediated dialogue with Mr. Frunză, we turn our attention to the Contents, where we notice that each of the titles of the book's sections begins with an "on": "On mystery and joy ..."; "On the literary martishor ..."; "On his mirrorings ..." etc. This naming option becomes all the more interesting when viewed through the eyes of a reader familiar with ancient and medieval works, because he will immediately recognize the same form of titles he has become accustomed to: "On the Soul"; "On the Heavens"; "On Generation and Corruption" - are some of the names of Aristotle's works; "On the City of God"; "On True Religion", Augustine calls his works; Dante writes a treatise "On Monarchy", and the list goes on and on. This "on" has a special status: it not only designates the subject that is treated in the pages of the books, but, in the case of the ancients and the medievals, it opens a complete research of the topic. When the same Augustine writes "De Doctrina Christiana" [On Christian Doctrine], he does not announce that he will deal, among other things, with Christian doctrine, but tells the reader that under this title he will encounter Christian doctrine, in its entirety, as Augustine sees it.

What does this "on" mean in the case of Sandu Frunză? Obviously it does not mean the same thing, so the role is different: this "on" renders the relationship of directing towards, of an approach of the author-reader duality to 
the books he read, establishing between them a spiritual relationship marked by a cosmic longing (Frunză, 2020, p. 26). This idea of the relationship between the reader and the book is one of the main ideas in Sandu Frunză's book.

Part I, of the two of which the book is comprised, entitled "Philosophical Counseling and Existential Communication", brings together commentary-reviews on books that are part of the basic bibliography in the field of philosophical counseling, which Mr. Sandu Frunză knows not only theoretically, but also practically, being both a teacher and a practitioner of this profession.

If I were to say that this book is a volume of book reviews, I would greatly reduce its value, because in addition to critical references, Sandu Frunză's texts also offer his own reflections on the topics covered in the books he refers to. It is true that many of those "on" are reviews, brief and comprehensive, that talk about the quality of books, but others are small articles and essays in which the author expresses his own ideas and thoughts, that resonated with the author or the theme of the book, with the reading experience by which the author-reader shares himself to us, the readers. What gives unity to diversity is the theme of man's relationship with books, also rendered by the subtitle "books could change your life". In this sense, Mr. Sandu Frunză's book offers an ontology of the book and an ethic of the relationship between the reader and the book.

Due to its content, Mr. Sandu Frunză's book can be seen as a volume of reading recommendations. In his commentary-reviews, Mr. Frunză offers a guide through the general and fundamental bibliography of philosophical therapy. Either we are talking about a reader who wants to become specialized in this field, or we are talking about a person who feels the need to "find himself, (...) improve himself, (...) rebalance and can even get some kind of everyday salvation" (Frunză, 2020, p. 50) that philosophy can offer, in Philosophy and daily communication, both types of readers can find recommendations for books that must be read, along with friendly explanations about how these books should be read in order for their existential-transformative effect to work at optimal parameters

Probably the most fascinating thing about this book is that it allows us a meta-reading, if I may use this term: reading this book is a lesson on how to read books. By reading this book, in it we read about the way the author reads books, so us, the readers of Sandu Frunză, have the opportunity to capture his reading, which highlights the role of books as bearers of ideas that have enough power to improve man's life, introducing him to a universe of meaning, sense and relationships, in a word - to the 
universe of communication. We read, therefore, in order to learn how to read.

If I were to answer the question "why should we have relationships with books?" - then the answer would be this: because they offer "orientation towards the meaning of existence, towards the values in life and towards the defining elements for the way man is in the world" (Frunză, 2020 , p. 47). From here, we can talk about the fact that reading is a form of existential therapy: a therapy through books, which would be suitable to stand next to Viktor Frankl's logotherapy, and which aims to clarify "the principles of our implicit, unexpressed philosophy, which acts under the sign of the natural in everyday life "(Frunză, 2020, p. 68).

Regarding the second part of the volume, entitled "The seduction of the joy of living", it seems that Sandu Frunză's volume repeats the fate of that great German thinker, whose work we are talking about while referring to its two stages: the first - in which he sought the being starting from the fundamental philosophical texts, and the second - in which he sought the same being in the works of poets like Hölderlin. Philosophy and everyday communication is similarly structured: if in the first part the author assumes the role of a specialist in philosophical counseling and guides the reader among the main building blocks - the essential titles - of this field, in the second part, he is "swept away" (Frunză, 2020, p. 248) by the art of poets, by the freedom that poetry offers, by the homilies of theologians, by the divine beauty of the Holy City. Being a collection of commentary-reviews mainly on volumes of poetry and theology books, the spirit of this part is different from the first, being much more personal, addressing especially the register of sensitivity than the intellect.

At first glance, the volume Pbilosophy and everyday communication may seem heterogeneous, being comprised of several texts that address very varied topics, even if similar. But these parts, different and yet similar, revolve around a gravitational core, which gives unity to the whole volume, which is the main idea that: there are tools that can help us in our daily confrontation with existence, ethical, philosophical, communication and relationship tools, and one method of accessing them is, incidentally, the simplest - by reading books. What books? - those recommended by Sandu Frunză, for starters.

This thematic unity of the texts is also supported by two themes that, by their recurrence, show that they are essential for the author: love and death. Like Socrates, who claimed that although the only thing he knows is that he knows nothing, the only thing he is good at is love, Sandu Frunză says that he could always talk about "forms of the identity between love and 
death." (Frunză, 2020, p. 301). In this context, I will emphasize three ideas that I consider the most valuable: that "we learn the joy of life because we are dealing with the mystery of death" (Frunză, 2020, p. 247); that "death makes it easier for us to spend our lives" (Frunză, 2020, p. 247) and that "those who do not gradually learn to value their death, most likely means that they do not love their life enough" (Frunză, 2020, p. 247).

\section{References}

Frunză, S. (2020). Filosofie și comunicare cotidiană: cărțile ar putea să-ți schimbe viața [Philosophy and everyday communication. Books could change your life]. Lumen. 